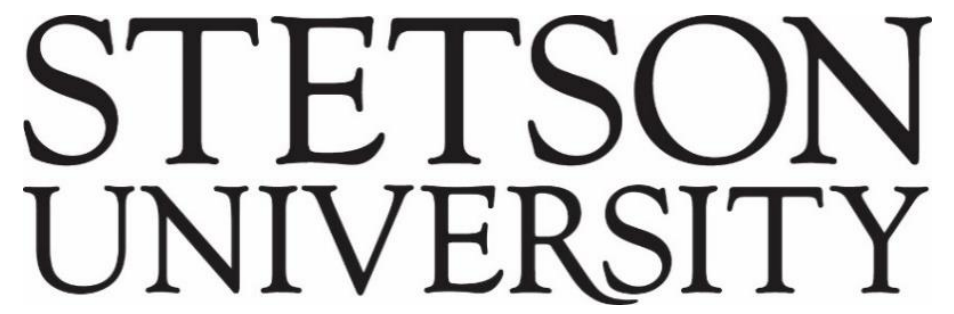

Voices of Reform: Educational Research to Inform and Reform

Volume $1 \bullet$ Issue $1 \bullet$ Article 3

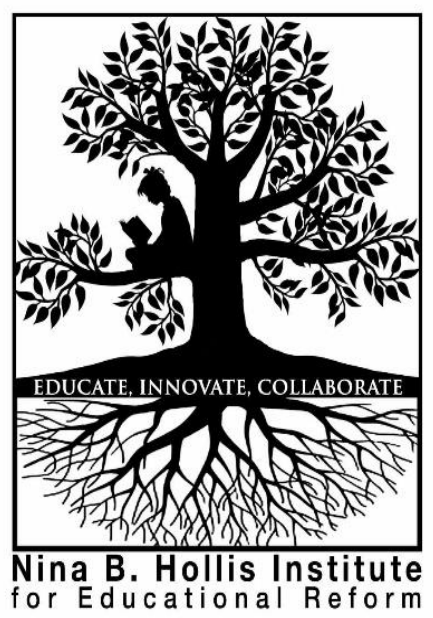

September 2018

\title{
When Parents Choose: The Influence of a \\ School of Choice on Family Engagement and Perception of Desired Educational Outcomes
}

Katherine A. Curry

Oklahoma State University

Follow this and additional works at: http://www.voicesofreform.com

Recommended Citation

Curry, K. A. (2018). When parents choose: The influence of a school of choice on family engagement and perception of desired educational outcomes. Voices of Reform, 1(1), 41-56. Retrieved from

https://www.voicesofreform.com/article/4486-when-parents-choose-the-influence-of-a-school-of-choice-of-familyengagement-and-perception-of-desired-educational-outcomes. doi: 10.32623/1.00005

http://dx.doi.org/10.32623/1.00005

Revisions

Submission date: May $31^{\text {st }}, 2018$

$1^{\text {st }}$ Revision: July $31^{\text {st }}, 2018$

Acceptance: August $17^{\text {th }}, 2018$

Publication date: September $15^{\text {th }}, 2018$ 


\title{
When Parents Choose: The Influence of a School of Choice on Family Engagement and Perception of Desired Educational Outcomes
}

\author{
Katherine A. Curry ${ }^{1}$ \\ ${ }^{1}$ School of Educational Studies \\ Oklahoma State University, United States \\ katherine.curry@okstate.edu
}

\begin{abstract}
A vast amount of research addressing school choice seeks to understand how and why parents/families choose schools. However, little is understood concerning the influence of choice on family beliefs and behavior. The purpose of this qualitative case study was to understand family perspectives, through the lens of Choice Theory (Glasser, 1998), of the influence of involvement in a school of choice on family perceptions of what it means to be engaged in their child's education and of desired educational outcomes. Findings indicate that participation in this school of choice influenced family on-campus engagement and that, even though families sought this school because of small class sizes and proximity to home, family perceptions of desired educational outcomes changed to a more academic focus as families engaged with the school and other families in the school. Choice Theory is utilized to explain these findings.
\end{abstract}

\section{Keywords}

family engagement, school choice, educational outcomes, Choice Theory

\section{Introduction}

The importance of family for academic success has been at the forefront of educational policy and research in the past several decades. For example, two important foci in $21^{\text {st }}$ Century school reform and research have been family engagement in education and school choice. Family engagement in education, a primary protective factor for children's academic success (Dearing et al., 2004; Ginsburg-Block et al., 2010), has gained attention in legislation and educational policy. This momentum is, in part, due to findings that family engagement, rather than income or social status, is the most accurate predictor of achievement in school (Learning Liftoff, 2015). Meta-analytic 
studies indicate academic socialization, or holding high expectations/aspirations for achievement, as the most salient form of engagement (Castro, et al., 2015; Fan \& Chen, 2001; Hill \& Tyson, 2009; Jeynes, 2005, 2007, 2012) followed closely by strategies that parents use at home including parenting style, reading with children, supervision, and providing in home learning activities (Jeynes, 2005, 2007). Traditional forms of family engagement are also important. Volunteering, attending parent/teacher conferences, attending events, and communicating with school staff are also predictors of student achievement (Castro, et al., 2015; Fan \& Chen, 2001; Hill \& Tyson, 2009; Jeynes, 2007, 2012).

Benefits of family engagement are numerous. These include higher grades and test scores, enrollment in more advanced programs, enhanced grade promotion and credit completion, better school attendance and homework completion, enhanced social skills and behavior allowing students to acclimate better to school environments, higher self-esteem, increased graduation rates, and enhanced attendance at post-secondary institutions (SEDL, 2013). The Chicago Consortium on School Research further indicates that when schools partner with parents and the community, the result can be "a systemic and sustained effect on learning outcomes for children and on whole school improvement” (SEDL, 2013, p. 5).

\section{School Choice}

A closely related issue in school reform efforts is the advancement of school choice (Chingos \& Blagg, 2017). Choice has increased in all states across the U.S (Belfield \& Levin, 2016; EdChoice, 2017) with the number of choice programs doubling between 2010 and 2016 (Fontaine \& Dave, 2017). At the end of 2010, fewer than 200,000 students utilized voucher, tax credit scholarship or education savings accounts across the nation (McShane, 2018). However, by the end of 2017, over 450,000 students were participating in more than 60 school choice programs (McShane, 2018). A range of choices has been posited by those who seek alternatives to the current government-funded educational system including education savings accounts, vouchers, tax-credit scholarships, and tax deductions/credits (EdChoice, 2018). Education options include traditional public schools, public charter schools, public magnet schools, private schools, online academies, and homeschooling (National School Choice Week, 2018). Advocates of the school choice movement suggest that choice places power in the hands of parents to choose schools that provide the educational outcomes they care most about (Harris \& Larsen, 2015). These advocates argue that "parents know what's best for their kids" and that parents and families are best equipped to decide which schools to attend (Kominiak, 2017, para. 1).

\section{Problem}

\section{Family Engagement}

Despite understandings of the importance of family engagement, and the fact that family engagement initiatives have become an integral part of reform efforts, many well-intentioned partnership efforts fail to meet their intended goals. For example, low-income and limited-English proficient families face barriers to engagement because they often lack access to the social capital and understanding of the school system necessary to take effective action on behalf of their children (Bolivar \& Chrispeels, 2010). Additionally, principals and teachers typically receive very 
little training for engaging families, and they often lack the requisite skills, knowledge, and confidence to sustain home-school partnerships (SEDL, 2013). A 2012 Metlife Survey of the American Teacher found that teachers and principals across the country identified family engagement as one of the most challenging aspects of their work (Markow, Macia, \& Lee, 2012).

\section{School Choice}

Critics of the school choice movement have raised concerns about whether school choice actually helps or hinders the most disadvantaged families (Chingos \& Blagg, 2017). They argue that limited choice opportunities or lack of parent knowledge about how to choose the best schools may limit the efficacy of parent choice. Research suggests that families, especially lower income families, often make schooling decisions based on factors other than academics (Harris \& Larsen, 2015). These factors include proximity to home, extended day schedules, or opportunities for extracurricular activities, especially for high school students (Kamenetz, 2015). Additionally, critics argue that school choice increases segregation due to the fact that parents often choose schools that enroll students with similar race, ethnicity, and economic status of their own children (Frankenberg, Siegel-Hawley, \& Wang, 2011; Garcia, 2008; Goyette, 2008; Rapp \& Eckes, 2007). These findings indicate that efforts to enhance student academic achievement and equity through choice options may be influenced negatively by actual parent choice practices. Thus, the debate continues regarding the salience of choice as a means to promote academic achievement in the context of equity and justice concerns.

Critics of the school choice movement have raised concerns about whether school choice actually helps or hinders the most disadvantaged families (Chingos \& Blagg, 2017). They argue that limited choice opportunities or lack of parent knowledge about how to choose the best schools may limit the efficacy of parent choice. Research suggests that families, especially lower income families, often make schooling decisions based on factors other than academics (Harris \& Larsen, 2015). These factors include proximity to home, extended day schedules, or opportunities for extracurricular activities, especially for high school students (Kamenetz, 2015). Additionally, critics argue that school choice increases segregation due to the fact that parents often choose schools that enroll students with similar race, ethnicity, and economic status of their own children (Frankenberg, Siegel-Hawley, \& Wang, 2011; Garcia, 2008; Goyette, 2008; Rapp \& Eckes, 2007). These findings indicate that efforts to enhance student academic achievement and equity through choice options may be influenced negatively by actual parent choice practices. Thus, the debate continues regarding the salience of choice as a means to promote academic achievement in the context of equity and justice concerns.

Guided by the Glasser's (1998) Choice Theory, the research questions are:

(1) How have parent perceptions of engagement changed as a result of attendance at this school of choice?

(2) How do school policies/practices influence family engagement?

(3) What needs/educational outcomes were parents attempting to meet by choosing this school and how have they changed as a result of attendance at this school of choice?

(4) How does Choice Theory explain these findings? 


\section{Theoretical Framework}

This study utilizes Choice Theory (Glasser, 1998) rather than the more commonly utilized framework of Rational Choice Theory to explain parent choice practices. Rational Choice Theory, a market-based theory used to explain how individuals make choices, is the most widely utilized theory to understand the school choice process (Krull, 2016; Wilson, 2016). This theory, based on behavioral psychology, suggests that individuals premeditate their actions to their greatest advantage by comparing the cost/benefit of every decision (Krull, 2016). Rational Choice Theory, in the context of school choice, places parents and students as consumers in an educational marketplace (Kelly, 2007) and is based on the fundamental reasoning that, given school choice options, parents will desire and select the highest academic alternative for their child (Chubb \& Moe, 1990; Krull, 2016; Lubinski \& Lubinski, 2014). Two general principles undergird rational choice theory: 1) individuals desire the best product or service; 2) people seek to maximize total utility in their choices (Herrnstein, 1990). Many proponents of the school choice movement premise their support on the belief that parents have the capacity and the resources to consider all options, to weigh and balance these options, and to make an informed, educated decision. However, when findings suggest that parents make choices for reasons other than academics (Frankenberg, Siegel-Hawley, \& Wang, 2011; Garcia, 2008; Goyette, 2008; Rapp \& Eckes, 2007), these findings are explained by indicating that many parents may actually lack the capacity to make the best schooling choices for their children (Krull, 2016), thereby invalidating fundamental support for choice. Specifically, the use of Rational Choice Theory stops short of providing an explanation of thought processes influenced in the exercise of choice because it simply explains how and why parents choose rather than processes that occur after parents exercise their choice options.

\section{Glasser's (1998) Choice Theory}

Choice Theory, developed in 1998 by William Glasser, however, has utility to provide such an explanation. Glasser's Choice Theory is based upon the foundational tenets of: 1) almost all behavior is chosen and 2) people are driven by genes to satisfy the five basic needs of survival, love and belonging, power, freedom and fun. This theory supports the understanding that when individuals exercise volitional choice in their behavior/actions, they are more psychologically satisfied, and relationships and self-efficacy are enhanced through the exercise of personal choice rather than through external control (Glasser, 1998). According to Choice Theory, exercising choice, whether in relationships, education, marriage or other aspects of life, can provide a platform for enhanced relationships, satisfaction, and self-efficacy.

The development of Glasser's theory supports the application of Choice Theory to school choice. Although Glasser initially applied his theory of personal choice to personal responsibility and personal transformation in counseling settings, Glasser expanded his theory to broad social issues such as education, management, and marriage. Specifically, the philosophical foundations which make Glasser's theory applicable for this study include the understandings that 1) all behavior is purposeful, 2) each person is doing "the best that he can" to meet his needs at the time, 3) a person can learn better ways to meet his needs, 4) a person will not change if there is nothing in it for 
him/herself, 5) by changing what we do, we change our thinking and feelings, and 6) an environment which reinforces positive behavior facilitates change.

\section{Methods}

Merriam's (1998) approach to case study research was employed for this study, and the theoretical framework, Glasser's Choice Theory (1998), helped to mold the research questions and provided focus to the study. This study was conducted in a private school, Northside Academy, located in a high-poverty neighborhood in an urban area in the Midwest. This school was chosen because of its emphasis on academic progress and the requirement for parents to volunteer time each month as a prerequisite for continued enrollment in the school. Additionally, before establishment of Northside Academy, few choice options existed in this area of the city. Therefore, for most of the parents at Northside, this school is the first opportunity to exercise choice and, therefore, the first school of choice that they have been involved with.

The school, established in 2015, enrolls 75 ethnically diverse students in grades PreK-3, and the Board of Directors/founders plan to expand upward by a grade level each year to meet educational needs in this community. The school was begun in fall 2015 as a proposed charter school, to be authorized by a State university. However, founders of the school proceeded with a private school model when the authorizer process slowed. Because founders desire eventual charter school status, only minimal tuition is charged to families ( $\$ 100$ per month), and AdvancEd accreditation standards have been implemented including the requirement of State certification for all teachers and administrators. All parents are expected to volunteer five hours each month at the school; however, those parents who cannot afford the $\$ 100$ tuition can substitute additional volunteer hours in place of required tuition. No student is turned away from the school due to inability to pay unless the parent/family member refuses to participate in the volunteer program.

Purposeful sampling was utilized for this study (Merriam, 1998). Data sources include interviews with six parents, two administrators, two teachers, observation of parent meetings and school events involving families, and document analysis of communication sent home to parents and through the school website. The two teachers who were purposefully selected had worked for the school since its opening in 2015. Parents were selected through purposeful and random sampling. The principal of the school provided a list of five names of parents who might be interested in participation. From that list, two parent names were randomly chosen. Following the interview with the first two parents, parents were invited to participate, through a flier explaining the study, as they dropped off and picked up their child from school. Because the school does not offer transportation to/from the school and all parents drop off/pick up their children, each parent had an equal chance of volunteering for the study. Interviews were conducted over a two week period of time near the end of the 2018 spring semester. Observations were conducted during drop off/pick up time, lunch, the school walk-a-thon, Saturday volunteer times, and parent/teacher endof-year conferences. Document analysis included student test scores, notes going home in homework folders, the school website, the school Facebook page, principal reports to the Board of Directors, and announcements posted on the bulletin board at the entrance of the school. 
Data analysis was a concurrent and interactive process; the process was ongoing as data were collected (Merriam, 1998) throughout the spring semester of 2018. The constant comparative and content analysis form of data analyses were followed by "consolidating, reducing and interpreting what people have said and what the researcher has seen and read" (Merriam, 1998, p. 178). According to Merriam (1998), data analysis is "the process of making meaning" (p. 187) applying the application of a constructivist epistemology as the researcher seeks to discover participant perceptions. Triangulation, member checking, and disclosure of researcher bias were performed to enhance internal validity and reliability (Merriam, 1998). Member checking was done by sending an electronic copy of the interview transcript to participant parents and asking for corrections/additions/revisions, if necessary.

\section{Findings}

The school is located on the northwest corner of a well-travelled intersection in a rented facility that has been modestly renovated to meet the needs of the school. Renovations include removal of several walls to enlarge classroom space and applying a fresh coat of paint to all interior spaces. Large windows and skylights provide natural light to enhance the fluorescent lighting in six large classrooms and a large, common meeting area. The building had originally been designed as a retirement home for older adults, so each classroom has easy access to renovated restroom facilities, and an office is conveniently located close to the front entrance to provide secure and safe monitoring of all who enter or leave the building. A very large, fenced playground provides space for recess and other outdoor activities. A large, but visibly temporary, sign identifies the building as Northside Academy.

The school employs two administrators, six teachers, and one administrative assistant. Seventy five students in grades PreK-3 attend Northside Academy. The student population primarily identifies as African American with a small minority of Caucasian and Native American Students. Approximately eighty-five percent of students live in poverty. Approximately ninety-five percent of the students at Northside Academy live in this community on the north side of the second largest metropolitan area in the State. The north side community was described as being a "tight knit" community where "everyone knows everyone or at least knows or is related to someone in common." The remaining five percent come from various locations within the city. No bus transportation is provided to students, and family members escort their children into and out of the building each day.

\section{Data Sources}

Two administrators, two teachers, and six parents/family members participated in individual, hourlong interviews. Both administrators earned master's degrees (one in engineering and the other in school administration). Mr. Smith, an African American male in his mid-thirties, serves as the Director of the school. Mr. Smith is responsible for communication with the surrounding community, working directly with the Board of Trustees, and assisting in promotion/recruitment of the school. Mrs. Long, a Caucasian female in her late thirties, serves as the principal of Northside Academy. She has an extensive history in school administration, having served as an elementary school principal in a nearby, high poverty district. Her responsibilities include 
supervising teachers, curriculum oversight, student discipline, and other responsibilities typically associated with an elementary school principal. The two teacher participants, both Caucasian, one male and one female, were both certified by the State as teachers at the elementary level. Ms. Cox currently teaches second grade, and she had ten years of experience as an elementary school reading specialist before coming to Northside. Mr. Brown currently teaches third grade, and he had four years of experience as $4^{\text {th }}$ grade teacher before coming to Northside Academy. Both teachers had been with Northside Academy since it opened in 2015.

The six parents/family members who participated in interviews included two fathers, three mothers, and one grandmother. The socio-economic status of family members who participated was diverse, and their educational background ranged from GED high school completion to graduate school. Table 1 summarizes the demographic characteristics of family participants.

Table 1. Family Participant Demographics

\begin{tabular}{|c|c|c|c|c|}
\hline Parent & Age & Education & $\begin{array}{l}\text { Number of Children } \\
\text { in Northside Academy }\end{array}$ & $\begin{array}{l}\text { Child(ren)'s } \\
\text { grades(s) and } \\
\text { gender }\end{array}$ \\
\hline Caucasian Male & Early 30 s & $\begin{array}{l}\text { Some High School } \\
\text { (GED) }\end{array}$ & 3 & $\begin{array}{l}2-\mathrm{K} \text { (twin girls); } \\
2^{\text {nd }}(\text { boy) }\end{array}$ \\
\hline African American Male & Mid 20s & Some College & 2 & $\mathrm{~K}$ (boy); $1^{\text {st }}$ (boy) \\
\hline $\begin{array}{l}\text { African American } \\
\text { Female }\end{array}$ & Late $20 \mathrm{~s}$ & $\begin{array}{l}\text { Some Graduate } \\
\text { School }\end{array}$ & 1 & $1^{\text {st }}$ (boy) \\
\hline $\begin{array}{l}\text { African American } \\
\text { Female }\end{array}$ & Early $30 \mathrm{~s}$ & High School & 1 & $2^{\text {nd }}$ (boy) \\
\hline $\begin{array}{l}\text { African American } \\
\text { Female }\end{array}$ & Late $50 \mathrm{~s}$ & High School & 2 & $\begin{array}{l}\text { PreK (girl); } 2^{\text {nd }} \\
\text { (boy) }\end{array}$ \\
\hline $\begin{array}{l}\text { African American } \\
\text { Female }\end{array}$ & Early 30 s & Some College & 1 & $\mathrm{~K}$ (girl) \\
\hline
\end{tabular}

\section{Parent Perceptions of Engagement}

Several themes emerged as a result of data analysis. Findings indicate that families had similar responses concerning engagement in their child's education before attending this school and that the school environment at Northside Academy was conducive for family engagement both on campus and off campus. Parents/family members described their previous involvement, before coming to Northside Academy, as consisting primarily of off-campus activities. Examples include making sure that students completed homework, "making sure (name of student) got to school on time," and "meeting (student) after school to walk home together." Two of the families reminded their children about the importance of education and encouraged them in their academic endeavors. They each explained that they desired involvement in their previous school settings; however, each 
felt limited by the structure or culture of the previous school. Parents explained that their previous involvement occurred primarily off campus as most found limited opportunity for on campus engagement or interaction with other parents in their previous educational settings. One parent explained, "it seemed like (name of former school) did not want us on campus." Another parent expressed, "(our former school) did not feel inclusive or inviting. It was like we were not welcome." Another explained, "they (former teachers) lacked cultural competency. They did not know how to engage my son." Parents expressed that they, previously, had relied on community resources or family relationships for support. Community resources included the public library, a nearby tutoring center, and a community center that offered after school activities.

In contrast, the environment at Northside Academy was described as "very welcoming." One parent explained, "I've never been turned away or delayed." Another stated, "(Northside Academy) has a very welcoming environment. This place feels like an extension of home." A parent post on the Facebook page stated, "This is a wonderful school community with a family feel. Kids get the attention and instruction they need in a loving atmosphere." These parents each described themselves as "highly involved" or "very involved." Administrators explained that the vast majority or "almost all of the parents" are very involved in their child's education at Northside. One administrator explained, "If they aren't involved, we stay on them until they show up." A teacher explained, "parents must be involved if they want their child to stay at Northside."

\section{School Policies/Practices that Influence Family Engagement}

Administrator responses, observations, and document analysis supported parent perceptions of engagement. Administrators explained that parents are "expected to start involved and stay involved." One employee of the school explained, "involvement is an expectation in order for a child to stay in this school. When parents first come, they may not realize how big a factor involvement really is. We have some difficult conversations if they are not involved." Another explained, "after working in a traditional public school, I now know it (family engagement) is absolutely the difference maker for student success." School employees explained that parents/family members who cannot afford the one-hundred dollar tuition required each month can substitute payment by serving or volunteering at the school, and ten hours of service was understood to be equivalent to paying monthly tuition. An administrator explained the flexibility provided to families regarding their involvement by explaining, "I ask parents, "what would you like to do? How can we contribute? How can we make that happen?"' One administrator stated, "The hundred dollar requirement is simply a way to get families committed to Northside Academy. I would much rather have them up here volunteering their time than even paying the hundred dollars."

Family members who could not pay tuition served in a variety of capacities including assisting with student assessment, library work, reading to with students, serving lunch, supervising recess, changing lightbulbs and helping with light yard work. Parents also found opportunities to volunteer by helping with school events such as a walkathon, book club or holiday parties. Observations made during the regular school day confirmed parent presence on campus. Parents walked children in and out of the school each day, and parents participated in activities such as reading to children, serving lunch, and helping with library time. 
In addition to volunteer work substituting for payment of monthly tuition, all parents were expected to attend volunteer clean up days at school, held one Saturday each month. This time was not counted toward tuition payment for non-paying parents. Administrators explained that required volunteer activities prompted families to "see the importance" of their involvement and to encourage their presence on campus during the school day. A teacher stated, "when kids realize that the 'long arm of the parent' reaches into the classroom and that learning is a priority, it influences the kids." Another suggested, "parent involvement here does make the difference (in student progress)."

As a result of required volunteer hours, the opportunity to substitute ten hours of volunteer work for tuition payment, expectations for involvement expressed by administrators and teachers, parents explained that their involvement/engagement had increased as a result of sending their child(ren) to Northside Academy. One parent explained, "(Northside Academy) has surprised me a great deal. I am very pleased that my child goes (to school) here, and I want to be more involved." Another explained, "I like to have a say (in my child's education), and I like to be involved. I have found that opportunity here." Parents explained that relationships with teachers and administrators were based on positive conversations about their child's progress rather than "only approaching me when (name of child) did something wrong - as in our previous school." These interactions encouraged parents to become more participative in their child's education.

Additionally, relationships have evolved between families, fostering further engagement. Parents have formed a Parent/Teacher Organization (PTO) and have established a Facebook page where parents can interact with each other. This Facebook page includes school announcements and reminders of upcoming due dates. Families also utilize a text reminder app called "Remind" to communicate. One parent explained the result of parent collaborative efforts in hiring a tutor during after school hours to address student reading deficiencies. She explained, "we were able to work together to solve a problem that many of us were having, and the administrators supported our efforts." Another example of family collaboration is that, even though many live in impoverished circumstances, they often work together to supply lunch for students. The school does not offer lunch services to students and expects parents to pack lunches. Parents, however, worked together to prepare and provide lunches for students on Tuesdays, Wednesdays, and Thursdays so that families only need to pack lunches two days during the week.

\section{Parent Perceptions of Desired Educational Outcomes}

Desired educational outcomes which motivated these families to seek attendance at Northside include small class sizes, close proximity, knowing someone whose child attended the school, and the ability to "know what is going on in my child's education" (Parent Interviews, 2018). The most common response to questions regarding family motivation to come to Northside Academy was "small class sizes." Parents explained, "I wanted something more... something different (than we were getting in our previous school)." One parent stated that her son, an African American, was taught by Caucasian teachers and that he was often corrected for distracted behavior in the classroom. She stated, 
I didn't want my son labeled as a problem child. Here (at Northside Academy), there is a welcoming environment. They allow him to learn and "be a child." In (name of his other school), they expected him to always sit still and not ask questions.

One parent explained, "there were just so many kids in his class at (name of previous school) that the teachers just wanted them to sit down and be quiet. My child quickly lost interest."

When asked to be specific about what they are looking for at Northside Academy, parent descriptions of desired educational outcomes remained very general and holistic. For example, parents explained that they were looking for "a good education," "a better attitude about the work that (name of child) is doing in school," "the ability for (name of child) to get along with other children," and "an opportunity to continue to grow." One parent stated, "I want him to continue to grow so that he doesn't lose the foundation of what he already has. I want him to be able to thrive anywhere like (parent mentioned the names of several high performing private schools in the metropolitan area)." Administrator responses to questions regarding parent perceptions of desired educational outcomes supported parent responses. One administrator explained, "when they come here, they want a 'good education,' but they don't always know how to explain what they are really looking for or what that means." This administrator further explained,

these parents want something better for their children; they just may not know how to go about doing it. They may not look at test scores, but they compare their kids with other kids. If they see someone else's child doing well and presenting him/herself confidently, they will say, 'I want that for my child.'

An employee of the school explained that parents want their children to "be productive citizens" and that they want more than academics. She explained, "these parents believe that there is more to life than reading or math scores." Parent responses supported this understanding. One parent stated, "all (name of previous school) cared about was my son's reading and math scores. I know those are important, but I want so much more for him. He has to learn to get along well in the world." The school's emphasis on character building supported parent perceptions. The school has recently adopted Steven Covey's (2014) Leader in Me framework to teach individual responsibility. All parent participants were familiar with the common language of Leader in Me and expressed appreciation for the character development aspect of the school.

\section{Parent Perceptions of Educational Outcomes as a Result of Attending Northside Academy}

As noted, parents responded to questions about goals for their children with answers that presented a holistic approach to growth and development. However, what these parents did not expect was that they would better understand their child's progress in reading programs, homework assignments, and standardized tests as a result of attending Northside Academy. A strong emphasis on academics has enhanced parent expectations for their children. Parents explained, "This school has helped me understand that my child can learn. He can do better," and "Success means not just showing up every day but doing better on his papers (homework)." A school strategy that enhances parent understandings is participation in goal setting teams, part of the Leader in Me (Covey, 2014) curriculum, where the teacher, parent, and student work together to set individualized academic 
goals. Expectations to graduate from high school and eventually attend college are frequently communicated, and parent desire to "expand what (name of child) sees outside of this neighborhood" is a common goal. One parent emphasized the importance of her child "getting into a good college. She has to get good grades and do well on tests to do that." Administrator responses supported this understanding. One explained, "Most of these kids don't know they are living in poverty. To them, this is 'normal.' We want to change mindsets - to expect more out of them than has ever been expected. We are creating a culture of high expectations." A teacher responded,

In (name of previous school where he/she worked), even when we gave families tools to work with, parents didn't know what to do with them. Parents didn't realize that their children were falling behind. When they get here, "a lightbulb goes off." They begin to understand that their children need more support from home, and they learn to expect more (from their children).

Another explained, "Goals change from 'my child made it through school without getting in trouble to 'I want my child to graduate from high school and have choices about his/her life."

The Leader in Me (Covey, 2014) program is another aspect of the school that has influenced parent perceptions of desired outcomes. This character education program has provided a common language for "personal responsibility" and has served as a platform for enhanced educational goals. Parents expressed appreciation for the character development program because it aligns with their holistic approach to education. Teachers emphasized the fact that very early in their education, the message is presented to students that "you can choose to get an education or not. The choice is yours. We are here to help you. We have high expectations for you, and we expect you to meet them." Teachers explained that parents are often surprised by the expectation of personal responsibility placed on children and that they often come to the school without an understanding of the relationship between behavior and academic success. An administrator stated, "Very rarely will you find a student who carries himself well and makes poor grades in school. It is all about learning to manage their behavior and becoming personally responsible for their choices." One parent explained, "I am surprised by how independent (name of child) is expected to be. I have started pushing her a bit more." Observations confirmed the emphasis of the Leader in Me program at the school. Teachers frequently utilized the language of the program, and signs were posted throughout the school reminding students of the basic tenets of personal responsibility.

\section{Discussion}

The philosophical foundations of Glasser's (1998) Choice Theory provide a lens to explain findings from this study. Glasser contends that 1) all behavior is purposeful and 2) each person is doing the best that he can. Families in this study chose Northside Academy based on their perceptions of desired educational outcomes. Even though families expressed these desired outcomes in holistic terms, such as desiring a "good education," all families expressed that they had goals in mind for their children when entering the school. For example, one parent explained that she wanted more for her children than simply learning to read and write. She expressed an understanding of the need for social and communication skills even though she did not specifically state those skills when initially questioned about her goals for her child. Several parents expressed 
the fact that they knew children who were attending Northside Academy, and they appreciated the behavior and actions of those children. One parent explained, "I wanted that same thing for my child." An administrator explained, "Life teaches you the value of an education. Some of our parents want their children to receive the education that they did not get." For many of these parents, choosing Northside Academy was a deliberate choice, and they were "doing the best that they could" to provide educational opportunities for their children.

Glasser's third philosophical foundation suggests that individuals can learn better ways of meeting their needs. For these parents, interacting with teachers and administrators, particularly in goal setting sessions, helped parents understand how to better help their children. Parents, teachers, and students met together to discuss individual student progress. During each of these meetings, the team set target goals. Goals included the areas of reading, math, student behavior, attendance, or any other area of concern that arose during the conversation. The emphasis on character through personal responsibility is also an example of learning better ways to meet the needs of their children. Parents expressed appreciation for this character building program, and they learned to use the common language of Leader in Me to reinforce what students were learning in school. Several parents indicated that they did not understand how much to expect from their child, both academically and behaviorally, before entering Northside Academy. This evidence of learning is explained by Glasser's third premise.

Glasser's fourth premise, a person will not change if there is nothing in it for him/herself, seemed to be satisfied as these parents learned how to better help their children. They all explained that their desire was to be highly engaged; to these parents, choosing Northside was an extension of their responsibility as a parent. Many expressed that they did not have the opportunity or the skills to support their child's education before coming to Northside. They perceived their involvement at Northside as helping them to fulfill their parental responsibilities as they encouraged their children in their educational efforts. Several also found support for behavior problems that their children were experiencing in their previous schools. Northside Academy, because of smaller class sizes, provided an opportunity for their children to be successful as classroom rules were relaxed to meet the needs of the student.

Collaborative efforts between the school and parents align with Glasser's fifth premise (by changing what we do, we change our thinking and feelings) and sixth premise (an environment which reinforces positive behavior facilitates change). Parents were expected to volunteer at school activities, and their engagement was a prerequisite for continued enrollment. As parents volunteered, they began to understand that they were welcome on campus and that their presence was important for the success of their child. Additionally, parents were treated as partners as they were expected to collaboratively establish learning goals for their student. High expectations from administrators and teachers for involvement and educational outcomes provided an environment which reinforced participative behavior. As a result, parent expectations for their children increased when they were included in goal setting activities and as they volunteered in various capacities in the school. Additionally, parents learned from communicating with each other, and they found a stronger "voice" when they worked together to find solutions to common needs. An administrator explained the emphasis on reinforcing positive behavior, "When playing golf, who 
shoots for par? We all want something more. It's the same with these parents. They just have to learn what to expect from their child."

\section{Implications for Practice, Research, and Theory}

\section{Practice}

Implications for practice include challenging dominant narratives about choice and what choice means for marginalized families. Findings from this study indicate that exercising choice can facilitate equitable alliances where families grow in expertise and engagement. Treating parents as partners, as this school did with educational goal setting and with expectations for volunteerism, can enhance understanding of family engagement in the educational process and of desired educational outcomes. These findings suggest that this school, when it placed priority on academic achievement and took the time to facilitate relationships with parents and between parents, enhanced family engagement and parent expectations for their children. Additionally, findings from this study hold implications for administrator preparation programs. Preparation programs that encourage an inclusive, empowering mindset toward families may promote success in this challenging aspect of the educator's role.

\section{Research}

Additional research is needed to gain a better understanding of the influence of choice within all school settings. Creating opportunities for parents to exercise choice, whether in traditional or choice school settings, may be a critical practice for enhancing parent engagement in education. For example, in a traditional public school context, choice may mean allowing parents to have a greater "voice" in the educational trajectory of their children. Following Glasser's (1998) Choice Theory, a person can learn better ways to meet his/her needs. Findings from this study support this contention. Glasser also postulates that, by changing what we do, we change our thinking and feelings, and an environment which reinforces positive behavior facilitates change. This choice experience allowed parents to engage in ways that they had not been able to in the past. This school also reinforced family engagement and setting high expectations through its volunteer requirements. Additional research is needed, in a variety of school contexts, to understand the influence of school practices on parent perceptions of engagement and educational outcomes and whether or not those perceptions can be altered by a change in opportunities regarding choice for parents.

These findings also suggest that connecting parents to other parents can be an important resource for engagement. These findings support findings in the literature (Curry \& Adams, 2012; Sheldon, 2002) concerning the influence of involved parents on other parents. Additional research could be conducted to determine if mobility rates in highly mobile districts may be lowered by enhanced parent choice as parents "buy in" to the education of their children and as they develop relationships with other parents, teachers, and administrators in a school.

\section{Theory}

Implications for theory are an important aspect of this study. By utilizing Glasser's Choice Theory (1998) rather than Rational Choice Theory, this study expanded understandings of what happens 
after parents choose. This understanding is important because explaining how individuals are changed by exercising choice, rather than simply understanding how and why families choose, adds to current understandings regarding the influence of choice. While schools may not be able to control how and why families choose, they can influence expectations for involvement, and they can influence parent perceptions of desired educational outcomes. Further research is needed to understanding of the influence of choice. The lens of Glasser's (1998) Choice Theory has potential to expand understandings of family engagement in theory, research, and practice.

\section{Limitations}

As with all research, this study contained several limitations. It is likely that family members who volunteered to participate in this study were among the most engaged parents/family members in the school. These parents all described themselves as "highly involved" and expressed a sincere desire for enhanced engagement. Additionally, it is likely that parents who choose a choice school are more actively engaged in their child's education simply because the act of choosing requires participation/involvement in the educational process. However, findings from this study suggest that engaging in choice activities, even among highly involved parents, provided a platform for further engagement and goal attainment. It is recognized that this school placed a priority on family engagement and required family participation for continued enrollment at the school. Other schools of choice may not emphasize engagement as Northside Academy does. However, utilizing Glasser's (1998) choice theory depended upon an environment that valued and promoted family engagement. Further study could provide greater understanding of the undergirding philosophy that "an environment which reinforces positive behavior facilitates change." This school considered family engagement as "positive behavior," whereas, other schools of choice may not have the same emphasis. Additional research is needed to understand the influence of choice in schools that do not require family participation/engagement for continued enrollment.

\section{References}

Belfield, C.R., \& Levin, H.M. (2002). The effects of competition between schools on educational outcomes: A review for the United States. Review of Educational Research, 72, 279-341.

Bolivar, J. M., \& Chrispeels, J. H. (2010). Enhancing parent leadership through building social and intellectual capital. American Education Research Journal, 48(1), 4-38.

Castro, M., Expósito-Casas, E., López-Martín, E., Lizasoain, L., Navarro-Asencio, E., \& Gaviria, J.L. (2015). Parental involvement on student academic achievement: A meta-analysis. Educational Research Review, 14, 33-46.

Chingos, M.M., \& Blagg, K. (2017). Who could benefit from school choice? Mapping access to public and private schools. Retrieved November 7, 2017, from https://www.brookings.edu/research/who-could-benefit-fromschool-choice-mapping-access-to-public-and-private-schools/

Chubb, J., \& Moe, T. (1990). Politics, markets, and America's schools. Washington, D.C.: Brookings Institutional Press.

Covey, S. (2014). The leader in me: How schools and parents around the world are inspiring greatness, one child at a time. London: Free Press.

Curry, K., \& Adams, C. (2012). Parent social networks: A resource to shape parent responsibility. In M. DiPaola \& P. Forsyth (Eds.), Contemporary Challenges Confronting School Leaders: Research and Theory in Educational Administration, (pp. 215-237). Charlotte, NC: Teachers College Press.

Dearing, E., McCartney, K., Weiss, H.B., Kreider, H., \& Simpkins, S. (2004). The promotive effects of family educational involvement for low-income children's literacy. Journal of School Psychology, 42, 445-460. 
EdChoice. (2017). The ABCs of School Choice. Retrieved June 23, 2018, from

https://www.edchoice.org/research/the-abcs-of-school-choice/

EdChoice (2018). Fast facts on school choice. Retrieved June 25, 2018, from http://www.edchoice.org/ourresources/fast-facts

Fan, X., \& Chen, M. (2001). Parental involvement in students' academic achievement: A meta-analysis. Educational Psychology Review, 13(1), 1-22.

Frankenberg, E., Siegel-Hawley, G., \& Wang, J. (2011). Choice without equity: Charter school segregation. Education Policy Analysis Archives, 19(1): 1-96.

Fontaine, C., \& Dave, K. (2017). Spectrum of trust in data: New York City parents navigating school choice. Data and Society. Retrieved June 23, 2018, from https://datasociety.net/pubs/ecl/DataSociety_Spectrum of Trust_in_Data2018_M.pdf

Garcia, D. (2008). Academic and racial segregation in charter schools: Do parents sort students into specialized charter schools. Education and Urban Society 40(5): 590-612.

Ginsburg-Block, M., Manz, P.H., \& McWayne, C. (2010). Partnering with families to foster early achievement in reading and mathematics. In S. L. Christenson \& A. L. Reschly (Eds.). The handbook on school family partnerships for promoting student competence (pp. 176-203). Oxford: Routledge/Taylor and Francis Group.

Glasser, W. (1998). Choice theory: A new psychology of personal freedom. New York: HarperCollins.

Goyette, K. (2008). Race, social background, and school choice options. Equity \& Excellence in Education 41(1): 114-129.

Harris, D.N., \& Larsen, M.F. (2015). What do parents want and why? Policy brief and technical report of ERA-New Orleans' paper on school choice post-Katrina. Education Research Alliance. Retrieved April 23, 2018, from https://educationresearchalliancenola.org/files/publications/120717-Harris-Larsen-Demand-Informationand-the-Market-for-schooling.pdf

Herrnstein, R. J. (1990). Rational choice theory: Necessary but not sufficient. American Psychologist, 45(3), 356367.

Hill, N.E., \& Tyson, D.F. (2009). Parental involvement in middle school: A meta-analytic assessment of the strategies that promote achievement. Developmental psychology, 45(3), 740.

Jeynes, W.H. (2005). A meta-analysis of the relation of parental involvement to urban elementary school student academic achievement. Urban education, 40(3), 237-269.

Jeynes, W.H. (2007). The relationship between parental involvement and urban secondary school student academic achievement: A meta-analysis. Urban education, 42(1), 82-110.

Jeynes, W.H. (2012). A meta-analysis of the efficacy of different types of parental involvement programs for urban students. Urban education, 47(4), 706-742.

Kamenetz, A. (2015). A new study reveals much about how parents really choose schools. Retrieved November 7 , 2017, from https://www.npr.org/sections/ed/2015/01/15/376966406/a-new-study-reveals-much-about-howparents-really-choose-schools

Kelly, A. (2007). School choice and student well-being: Opportunity and capability in education. New York, NY: Palgrave MacMillan.

Kominiak, T. (2017). More families are choosing out: And academics in just one reason why. Retrieved April 25, 2018, from https://www.k12insight.com/trusted/families-academics-school-choice/

Krull, S. (2016). School selection patterns, choice and traditional public schools through the lenses of rational choice theory and behavioral economics theory. Theses and Dissertations. 1380. Retrieved fromhttp://dc.uwm.edu/etd/1380.

Learning Liftoff. (2015). How parental involvement benefits the entire educational process. Retrieved April 23, 2018, from https://www.learningliftoff.com/how-parental-involvement-benefits-theentire-educational-process/

Lubienski, C., \& Lubienski, S. (2014). The public school advantage: Why public schools outperform private schools. Chicago, IL: University of Chicago.

Markow, D., Macia, L., \& Lee, H. (2012). The MetLife survey of the American teacher: Challenges for school leadership. New York, NY: MetLife.

McShane, M. (2018). Play the long game on school choice: 2018 will not be the year of school choice and that's ok. US News and World Report. Retrieved June 24, 2018, from https://www.usnews.com/opinion/knowledgebank/articles/2018-01-03/2018-wont-be-the-year-of-school-choice-and-thats-ok

Merriam, S.B. (1998). Qualitative Research and Case Study Applications in Education. Revised and Expanded from "Case Study Research in Education." San Francisco, CA: Jossey-Bass Publishers. 
Curry: When parents choose: The influence of a school of choice of family engagement and perception of desired educational outcomes

National School Choice Week. (2018). What is school choice? 2018 trends. Retrieved June 24, 2018, from https://schoolchoiceweek.com/2018-trends/

Rapp, K.E., \& Eckes, S.E. (2007). Dispelling the myth of "White Flight": An examination of minority enrollment in charter schools. Educational Policy, 21(4), 615-661.

SEDL. (2013). Partners in education: A dual capacity-building framework for family-school partnerships. Retrieved April 23, 2018, from http://www.sedl.org/pubs/framework/FE-Cap-Building.pdf

Sheldon, S.B. (2002). Parents' social networks and beliefs as predictors of parent involvement. The Elementary School Journal, 102(4), 301-316.

Wilson, T. (2016). Interest, not preference: Dewey and reframing the conceptual vocabulary of school choice. Education Theory, 66(1-2), 147-163. 